\title{
Article \\ Catalyst Replacement Policy on Multienzymatic Systems: Theoretical Study in the One-Pot Sequential Batch Production of Lactofructose Syrup
}

\author{
Pablo Silva ${ }^{1} \mathbb{D}$, Vanessa Arancibia ${ }^{1}$, Daniela Cid ${ }^{1}$, Oscar Romero ${ }^{2} \mathbb{D}$, Andrés Illanes ${ }^{1}$ and Lorena Wilson ${ }^{1, * \mathbb{D}}$ \\ 1 School of Biochemical Engineering, Pontificia Universidad Católica de Valparaíso, Avenida Brasil 2085, \\ Valparaíso 2362803, Chile; pablo.silva@pucv.cl (P.S.); vanessa.arancibia@pucv.cl (V.A.); \\ daniela.cid@pucv.cl (D.C.); andres.illanes@pucv.cl (A.I.) \\ 2 Bioprocess Engineering and Applied Biocatalysis Group, Department of Chemical Biological and \\ Environmental Engineering, Universitat Autònoma de Barcelona, 08193 Bellaterra, Spain; \\ oscarenrique.romero@uab.cat \\ * Correspondence: lorena.wilson@pucv.cl
}

Citation: Silva, P.; Arancibia, V.; Cid, D.; Romero, O.; Illanes, A.; Wilson, L. Catalyst Replacement Policy on Multienzymatic Systems: Theoretical Study in the One-Pot Sequential Batch Production of Lactofructose Syrup. Catalysts 2021, 11, 1167. https:// doi.org/10.3390/catal11101167

Academic Editor: Ulf Hanefeld

Received: 29 July 2021

Accepted: 20 September 2021

Published: 27 September 2021

Publisher's Note: MDPI stays neutral with regard to jurisdictional claims in published maps and institutional affiliations.

Copyright: (c) 2021 by the authors. Licensee MDPI, Basel, Switzerland. This article is an open access article distributed under the terms and conditions of the Creative Commons Attribution (CC BY) license (https:/ / creativecommons.org/licenses/by/ $4.0 /)$.

\begin{abstract}
One-pot systems are an interesting proposal to carry out multi-enzymatic reactions, though this strategy implies establishing an optimal balance between the activity and operability of the involved enzymes. This is crucial for enzymes with marked differences in their operational stability, such as one-pot production of lactofructose syrup from cheese whey permeate, which involves two enzymes- $\beta$-galactosidase ( $\beta$-gal) and glucose isomerase (GI). The aim of this work was to study the behavior of one-pot sequential batch production of lactofructose syrup considering both enzymes immobilized individually, in order to evaluate and design a strategy of replacement of the catalysts according to their stabilities. To this end, the modelling and simulation of the process was carried out, considering simultaneously the kinetics of both reactions and the kinetics of inactivation of both enzymes. For the latter, it was also considered the modulating effect that sugars present in the medium may have on the stability of $\beta$-gal, which is the less stable enzyme. At the simulated reaction conditions of $40^{\circ} \mathrm{C}, \mathrm{pH} 7$, and $0.46\left(\mathrm{IU}_{\mathrm{GI}} / \mathrm{IU}_{\beta \text {-gal }}\right)$, the results showed that considering the stability of $\beta$-gal under non-reactive conditions, meaning in absence of the effect of modulation, it is necessary to carry out four replacements of $\beta$-gal for each cycle of use of GI. On the other hand, when considering the modulation caused by the sugars on the $\beta$-gal stability, the productivity increases up to $23 \%$ in the case of the highest modulation factor studied $(\eta=0.8)$. This work shows the feasibility of conducting a one-pot operation with immobilized enzymes of quite different operational stability, and that a proper strategy of biocatalyst replacement increases the productivity of the process.
\end{abstract}

Keywords: multi-enzymatic reactions; one-pot; catalyst replacement policy; modulation factor; sequential batch; lactofructose syrup; $\beta$-galactosidase; glucose isomerase

\section{Introduction}

The increasing use of enzymes as industrial catalysts [1-3], has evolved to the development of multienzyme processes [4-6], where two or more enzymes act coordinately to perform the conversion reaction [7]. An appealing proposal is to conduct the multi-step enzymatic reaction in a single vessel (one-pot) [8-11]. This strategy implies that the enzymes involved are able to act together without compromising their activity and operational stability, therefore reducing the intermediate product(s) inhibition, and avoiding unnecessary separation and purification steps [12-15]. In this way, fewer unit operations are required, solvent consumption reactor volume and operation time are reduced, yield is increased, and waste is considerably reduced [5]. However, the temperature and $\mathrm{pH}$ profiles of the enzymes can differ significantly, as well as their operational stability $[5,14,16]$. Therefore, compromised operation conditions should be established to optimally balance their activity and operational stability $[14,17]$, which is a key determinant of reactor performance $[18,19]$. 
In that direction, mathematical modeling is a powerful tool for predicting the process output before its implementation, allowing to explore different reactor configurations and modes of operation to early on select the most promising options that will later be validated experimentally [7]. Mathematical modelling has been used in the case of enzyme reactors to identify optimal operation conditions, maximize substrate conversion into product, increase productivity, and maintain substrate conversion (and therefore product quality) during reactor operation within pre-established margins of variation $[7,19]$.

Immobilization of enzymes is another powerful tool for its industrial implementation, usually producing a significant increase in enzyme stability and facilitating the reactor operation [4,20-22]. In the case of one-pot multienzyme systems, if each enzyme is immobilized separately, the resulting biocatalyst can be handled independently in a spinning basket reactor (Figure 1A) [5]. This configuration allows an easy control of the proportion of each biocatalyst required, their activity and operational stability; it also allows individual replacement of the spent immobilized enzyme according to its lifespan of use [14]. Since enzyme inactivation and its replacement is inevitable, modeling and simulation is a powerful tool for the effective use of the biocatalyst prior to replacement and the planning of reactor operation [23].
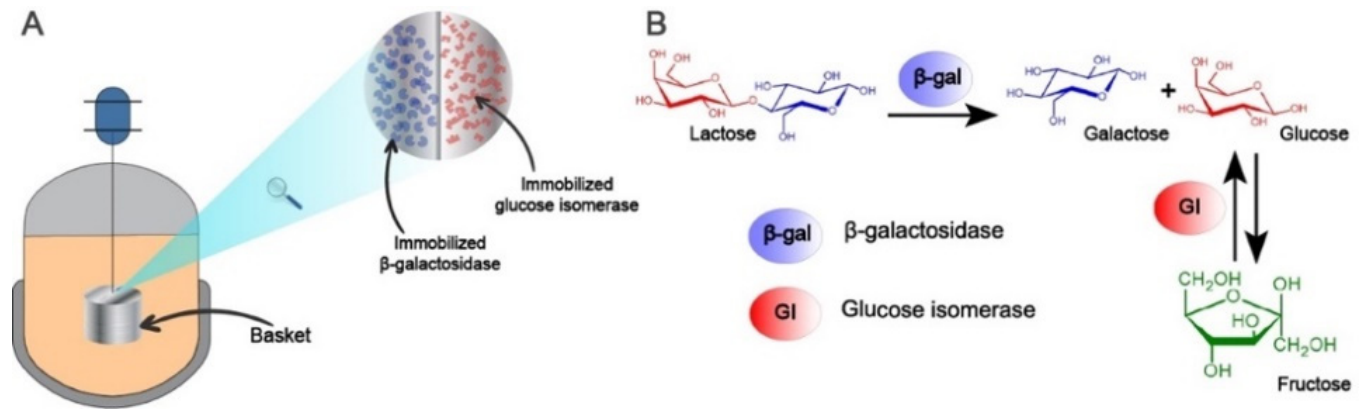

Figure 1. (A) Schematic representation of a spinning basket reactor with separate compartments for each immobilized biocatalyst. (B) Scheme of lactose hydrolysis with $\beta$-gal and glucose isomerization with GI.

A sound strategy for the upgrading of lactose is the production of lactofructose syrup (LFS) by the sequential hydrolysis of lactose with $\beta$-galactosidase ( $\beta$-gal) and the isomerization of the resulting glucose by glucose isomerase (GI) (Figure 1B). The kinetics of both enzymes have been well characterized, having significant differences in thermal stabilization [24-33]. The resulting product is a mixture of sugars (fructose, glucose, galactose, and residual lactose) with a sweetening power similar to sucrose $[8,19,34]$. The production of this syrup has been conducted in a sequential operation in two separate reactors for hydrolysis and isomerization; however, its production in a one-pot strategy with co-immobilized $\beta$-gal and GI has been recently reported [8]. It is well documented that substrates and products of reactions, as well as some sugars, exert a modulation effect on the stability of both enzymes [35-39]. In the case of $\beta$-gal, galactose exerts a positive modulation effect (protection) while the lactose modulation effect is negative and glucose has no effect $[40,41]$; in the case of GI, both glucose and fructose exert a positive modulation effect [32,42].

Using modelling and simulation tools, the purpose of this work was to study the behavior of the one-pot sequential batch production of lactofructose syrup considering both enzymes immobilized individually, in order to evaluate and design a strategy of catalyst replacement according to their stabilities. $\beta$-gal from Aspergillus oryzae immobilized onto poly(methacrylate) beads and commercial immobilized GI from Streptomyces murinus (Sweetzyme) were selected for the purpose of this work, where different scenarios were considered in terms of the modulation effects exerted by lactose and galactose on $\beta$-gal, which is the less stable enzyme. 


\section{Results and Discussions}

\subsection{Selection of Operating Conditions}

The performance of a one-pot sequential batch reactor for LFS production was simulated considering the thermal dependence of the kinetic and stability parameters of $\beta$-gal and GI at different GI/ $\beta$-gal activity ratio and temperatures (see materials and methods). The kinetics of LFS production per batch at three temperatures and three GI/ $\beta$-gal activity ratios are shown in the Figure 2. As expected, fructose production increases with a higher GI/ $\beta$-gal activity ratio approaching more rapidly to its equilibrium concentration. Similarly, increasing temperature favors fructose formation, given the thermophilic nature of GI. On the other hand, it can be observed that the rate of lactose hydrolysis decreases at the higher temperature as a result of $\beta$-gal inactivation.

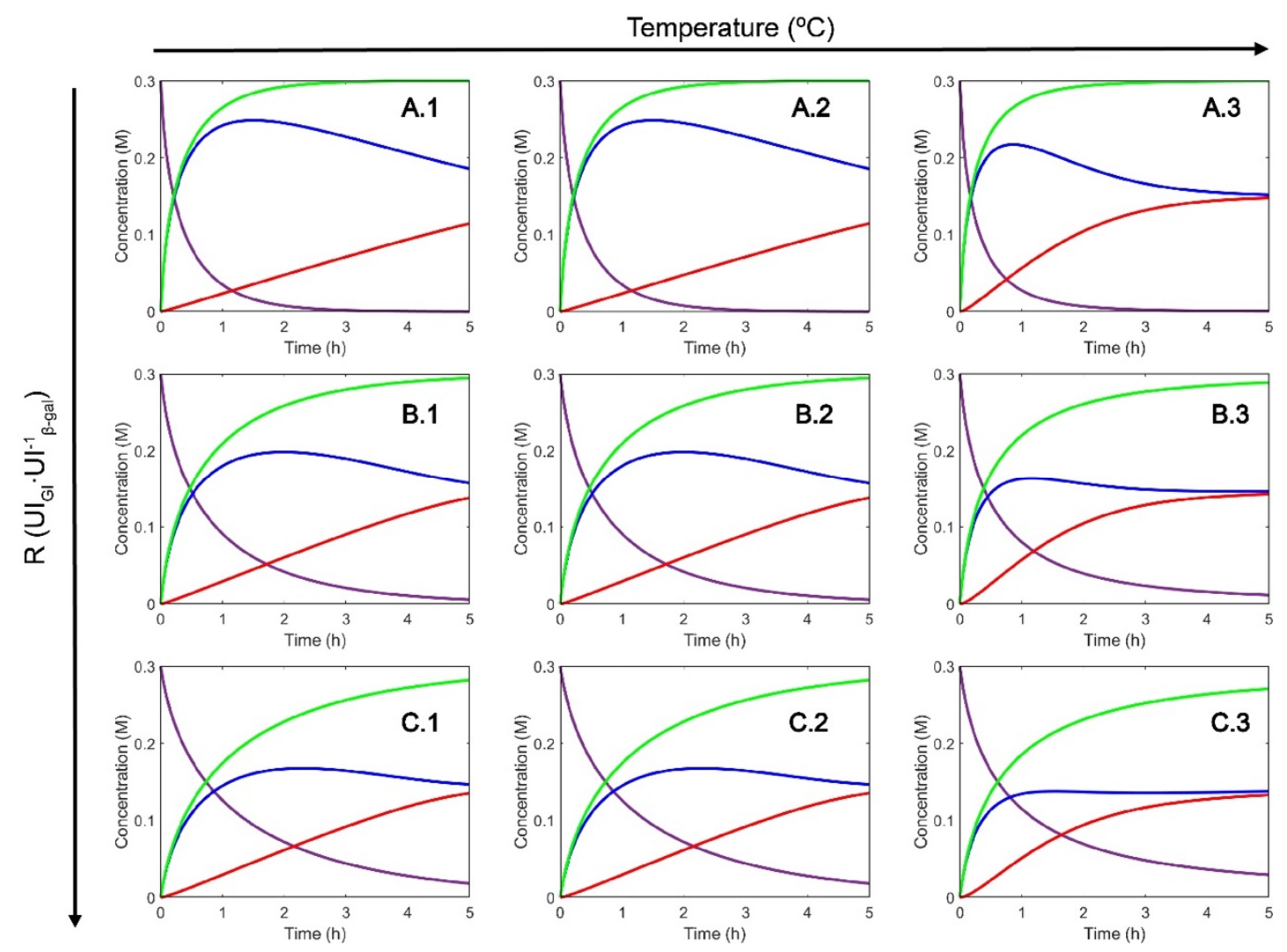

Figure 2. Substrates and products concentrations profiles during the one-pot production of lactofructose syrup in batch at different temperatures and GI/ $\beta$-gal activity ratio. (Temperatures: (1): $40{ }^{\circ} \mathrm{C}$, (2): $45^{\circ} \mathrm{C}$ and (3): $50{ }^{\circ} \mathrm{C}$. GI/ $\beta$-gal activity ratio: (A.1-A.3): 0.1; (B.1-B.3): 0.3 and (C.1-C.3): 0.5. Purple: lactose; Green: galactose; Blue: glucose; Red: fructose).

These results reflect the importance of both enzyme ratio and temperature on reactor behavior, and the need to identify conditions that maximize the production of fructose syrup. To identify this condition, an evaluation of the effect of temperature and enzyme ratio on the productivity was carried out. The effect of GI/ $\beta$-gal activity ratio on the productivity of a batch of fructose syrup production for three different temperatures can be found in the Supplementary Materials. An optimum GI/ $\beta$-gal activity ratio for each temperature resulting in $0.46,0.25$, and 0.18 (IUGI/IU $\beta$-gal) corresponding to 40,45 , and $50{ }^{\circ} \mathrm{C}$, respectively (Figure S4).

In order to select the temperature for the simulations, an analysis was carried out based on the specific productivity during one batch at different temperatures. Figure 3 shows the variation of the specific productivity related to $\beta$-gal in one batch conducted at the optimum GI/ $\beta$-gal activity ratio for each temperature. As it can be observed, specific productivities at 45 and $50^{\circ} \mathrm{C}$ are significantly lower than at $40^{\circ} \mathrm{C}$, because the mass of $\beta$-gal 
used is different at each temperature, being lower at 40 than at $50{ }^{\circ} \mathrm{C}$. This shows the strong influence of the inactivation of $\beta$-gal on the productivity due to the thermal inactivation.

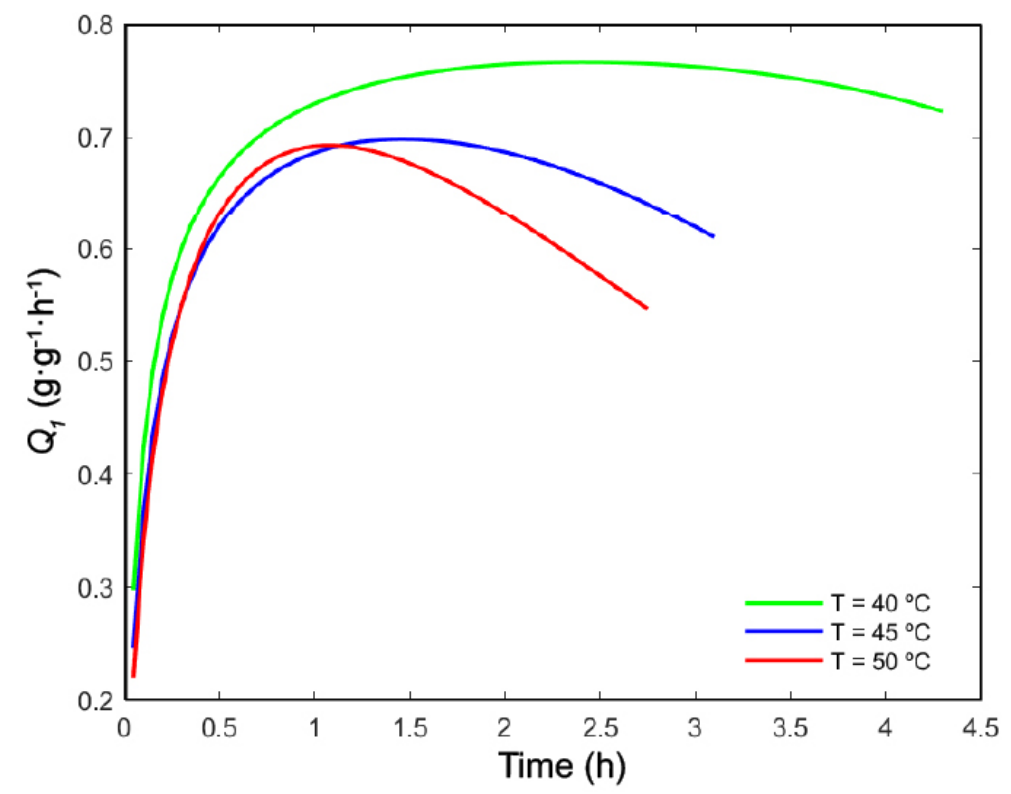

Figure 3. Specific productivity referred to $\beta$-galactosidase during one batch of lactofructose syrup production at different reaction temperatures and at the corresponding optimal GI/ $\beta$-gal activity ratio.

For the following simulations based on specific productivities, the temperature of $40{ }^{\circ} \mathrm{C}$ and an IG/ $\beta$-gal activity ratio of 0.46 (IUGI/IU $\beta$-gal) were selected, which are conditions that favor $\beta$-gal, the least stable enzyme in this case.

\subsection{Effect of Modulation of $\beta$-gal Stability on the Production of Lactofructose Syrup in One-Pot} Sequential Batch Operation

It has been shown that substrates and products of reaction (and other compounds like some polyols and sugars) may exert a modulation effect, usually protection, on enzyme stability $[38,43]$. In this case, it has been reported that galactose exerts a positive modulation (protection), but lactose modulation is negative [41]; therefore, stability under non-reactive conditions does not adequately predict the stability during reaction so that in many instances thermal inactivation of enzymes is overestimated [8].

Given the above, the eventual modulation effect that the sugars present in the reaction medium may have on the stability of $\beta$-gal was included, $\beta$-gal being the less stable enzyme. Under non-reactive conditions, the first order inactivation rate constant of $A$. oryzae $\beta$-gal was determined, obtaining a value of $0.0098 \mathrm{~h}^{-1}$ at $40{ }^{\circ} \mathrm{C}$ (see Supplementary Materials), which is higher than the inactivation rate obtained under reactive conditions [8]; thus reflecting the protective effect of the sugars. In addition, previous works have shown that the use of modulation factors is a good approximation to simulate the stability of enzymes under reactive conditions $[38,44]$. Therefore, it was decided to evaluate the effect of different magnitudes of the global (positive) modulation factor $(\eta)$.

Simulation of the one-pot production of LFS in sequential batch operation considering the operational stability of both enzymes with different global modulation factors $(\eta)$ was carried out. The simulation considers one cycle of use of GI, since it is the most stable enzyme, and the results are shown in Figure 4. 

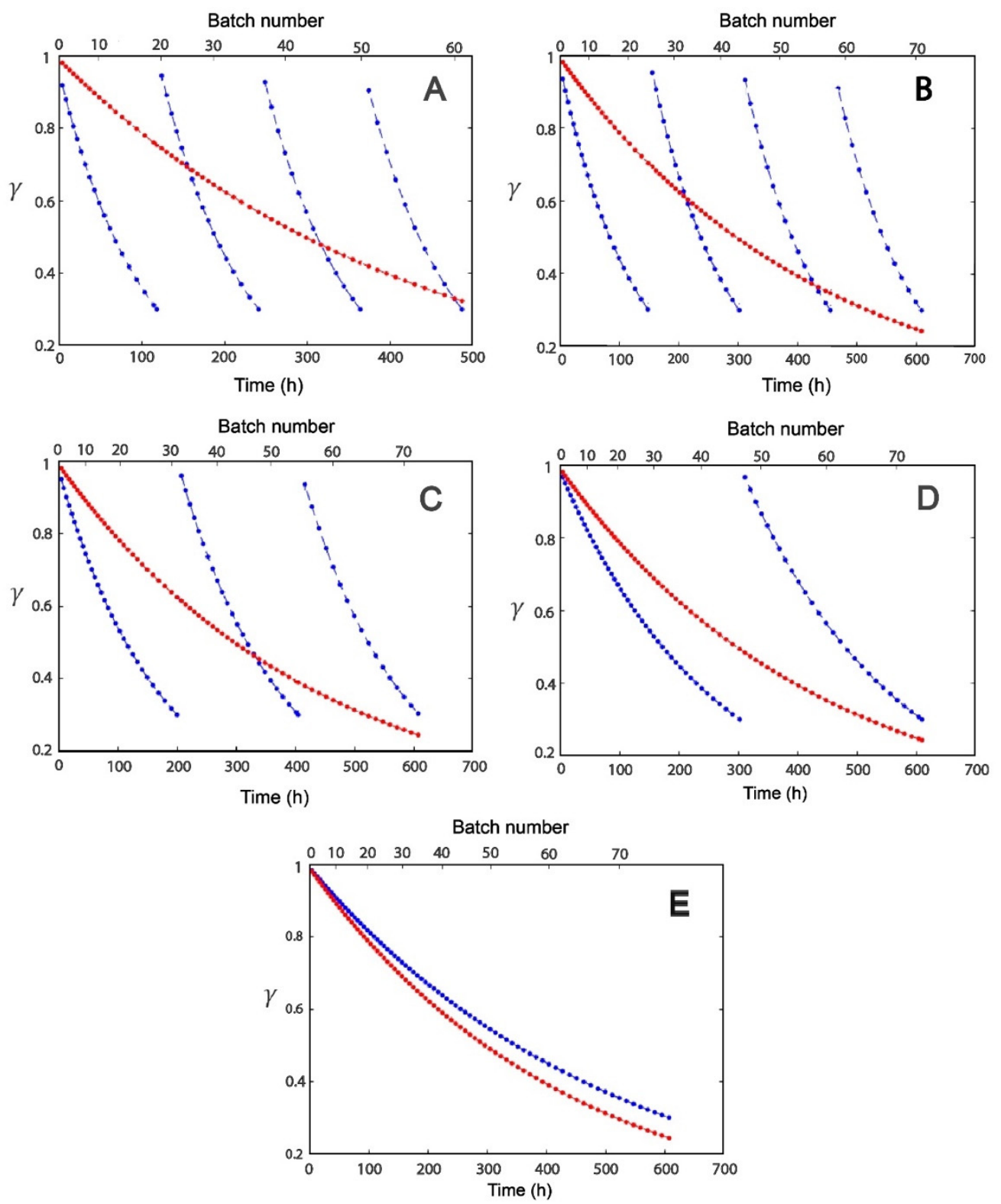

Figure 4. Operational stability of $\beta$-gal and GI in terms of reaction time and number of sequential batches during the one-pot production of lactofructose syrup in sequential batch operation. Simulations were performed considering $40{ }^{\circ} \mathrm{C}$, $\mathrm{pH} \mathrm{7,10 \% (w/w)} \mathrm{of} \mathrm{initial} \mathrm{lactose} \mathrm{concentration} \mathrm{and} \mathrm{GI/} \beta$-gal activity ratio of $0.46\left(\mathrm{IU}_{\mathrm{GI}} / \mathrm{IU}_{\beta \text {-gal }}\right) .(\mathbf{A}) \eta=0 ;(\mathbf{B}) \eta=0.2$; (C) $\eta=0.4$; (D) $\eta=0.6$; (E) $\eta=0.8$. Operational stability of $\beta$-gal: blue lines; stability of GI: red lines.

As expected, the simulation in Figure 4 shows that the number of cycles of use required by $\beta$-gal with respect to one cycle of GI decreases as a higher $\eta$ is considered. In the absence of modulation ( $\eta=0$; Figure $4 \mathrm{~A})$, it is observed that during one cycle of use of GI, the $\beta$-gal enzyme has to be replaced four times. Instead, when a $\eta=0.8$ is considered, one cycle of use of GI will match one cycle of $\beta$-gal use, so the replacement of both enzymes would in this case be synchronic.

Working with combi-crosslinked enzyme aggregates (combi-CLEAs) of $\beta$-gal and GI for the production of lactofructose syrup from lactose in one-pot batch operation, Araya, et al. [8] reported that the productivity of fructose remained constant for five batches with an accumulated time of $50 \mathrm{~h}$. This result is similar to the one obtained in this work, considering $\eta=0.4$ (Figure $4 \mathrm{D}$ ). Indeed, the decrease in productivity from the first to the ninth sequential batch in our simulation was $18.34 \%$, corresponding to an accumulated time during the nine batches of $48.6(\mathrm{~h})$. 
The effect of operational stability and the global modulation factor on the productivity of each batch was also evaluated and its evolution is shown in the Figure 5. Productivity decreases with the number of batches at all the evaluated conditions, as enzymes (especially $\beta$-gal) are progressively inactivated, so that the time required for each batch increases. It is important to analyze the productivity after each cycle of $\beta$-gal use; in this case, even though the productivity increases after $\beta$-gal replenishment, values obtained in the initial batches are no longer reached since GI is already inactivated to a certain extent. This situation worsens as the time of use of GI increases. After one cycle of use of GI, the reduction in productivity was of 63.8 and $71.7 \%$, the former corresponding to an absence of modulation, and the latter to a modulation factor of $\eta=0.8$. The results show that it is feasible to use two catalysts with different stability in a one-pot process, when both are immobilized independently, which allows to replace the more unstable catalyst at the right time, without losing the residual activity of the second enzyme, thereby enabling a more cost-effective use of the catalysts.
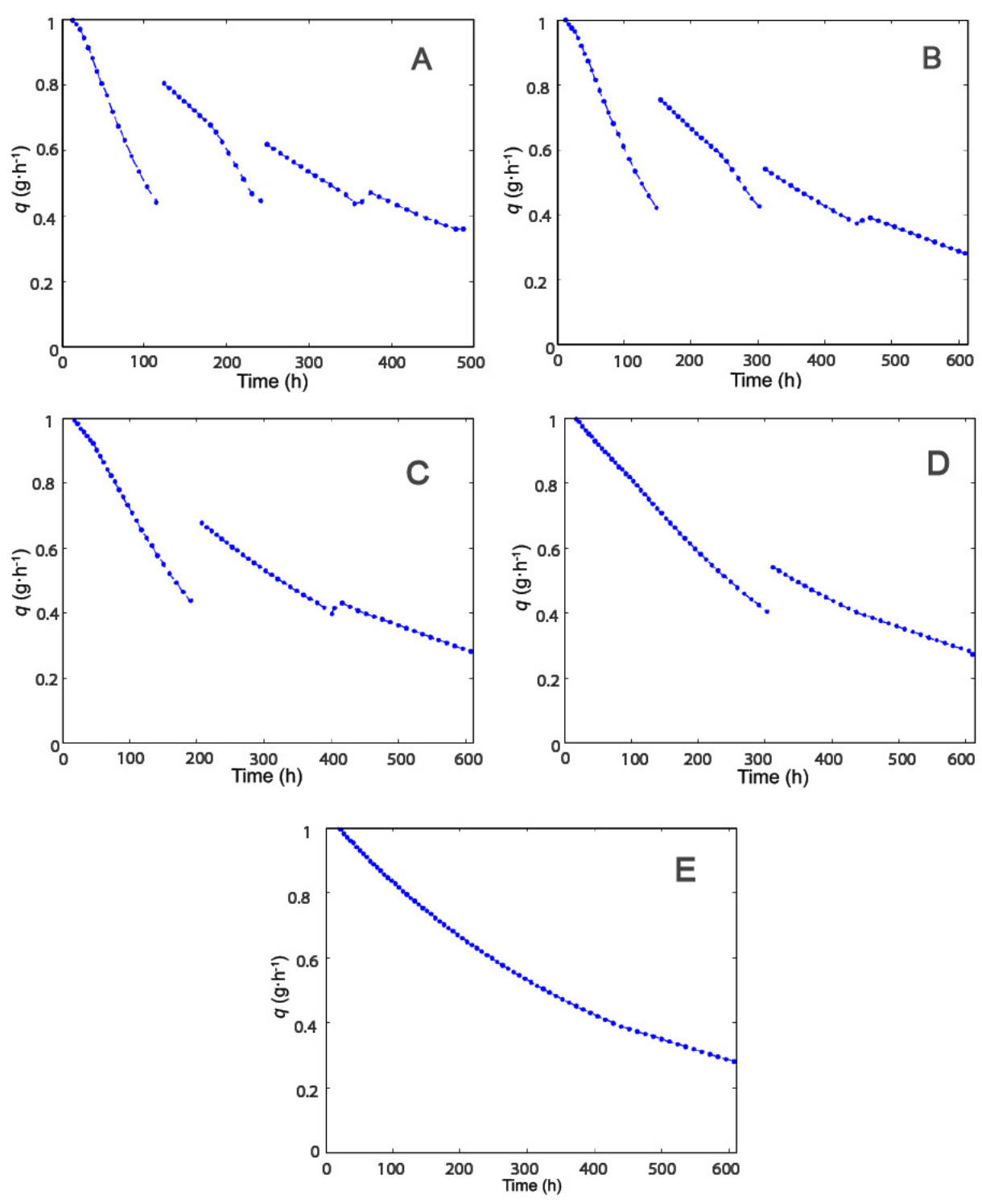

Figure 5. Evolution in productivity in sequential batch operation of lactofructose syrup production in one-pot considering one cycle of use of GI and one or several cycles of use of $\beta$-gal. Simulations were performed considering $40^{\circ} \mathrm{C}, \mathrm{pH} 7,10 \%(w / w)$ of initial lactose concentration and $\mathrm{GI} / \beta$-gal activity ratio of $0.46\left(\mathrm{IU}_{\mathrm{GI}} / \mathrm{IU}_{\beta \text {-gal }}\right)$. (A) $\eta=0 ;(\mathbf{B}) \eta=0.2 ;(\mathbf{C}) \eta=0.4 ;(\mathbf{D}) \eta=0.6 ;(\mathbf{E}) \eta=0.8$. 
Although other alternatives to compensate the enzyme inactivation have been discussed in the literature, such as the addition of fresh enzyme, the increase of the reactor temperature $[45,46]$ and the increase of the residence time in continuous reactor [19], none of them are compatible with the presented case of study. Moreover, the proposed catalyst replacement policy can be applied to other multi-enzyme systems where the enzymes involved might have quite different stabilities [17].

In order to assess the impact of the inactivation and the replacement of $\beta$-galactosidase on the production of LFS, the accumulated productivity was determined (see Equation (27)). The results show a decrease in accumulated productivity with the operation time (Figure 6). When inactivated $\beta$-gal is replaced by fresh enzyme, a slight increase in the accumulated productivity is observed because of the decrease of the times required in the initial batches. However, since GI is partially inactivated, the reaction times required in the initial batches are no longer sufficient to maintain the initial productivity. This effect is clearly noticeable after the first $\beta$-gal replacement and becomes less significant in the following. As a result, the number of batches that can be performed depends on the time of $\beta$-gal use (see Table S5). For all $\eta$ values studied, the number of batches per $\beta$-gal use decreases. This is a clear effect of the batch duration time, which is increasing because the GI has not been replaced in the reactor and therefore has less and less activity. Therefore, the productivity values keep declining.

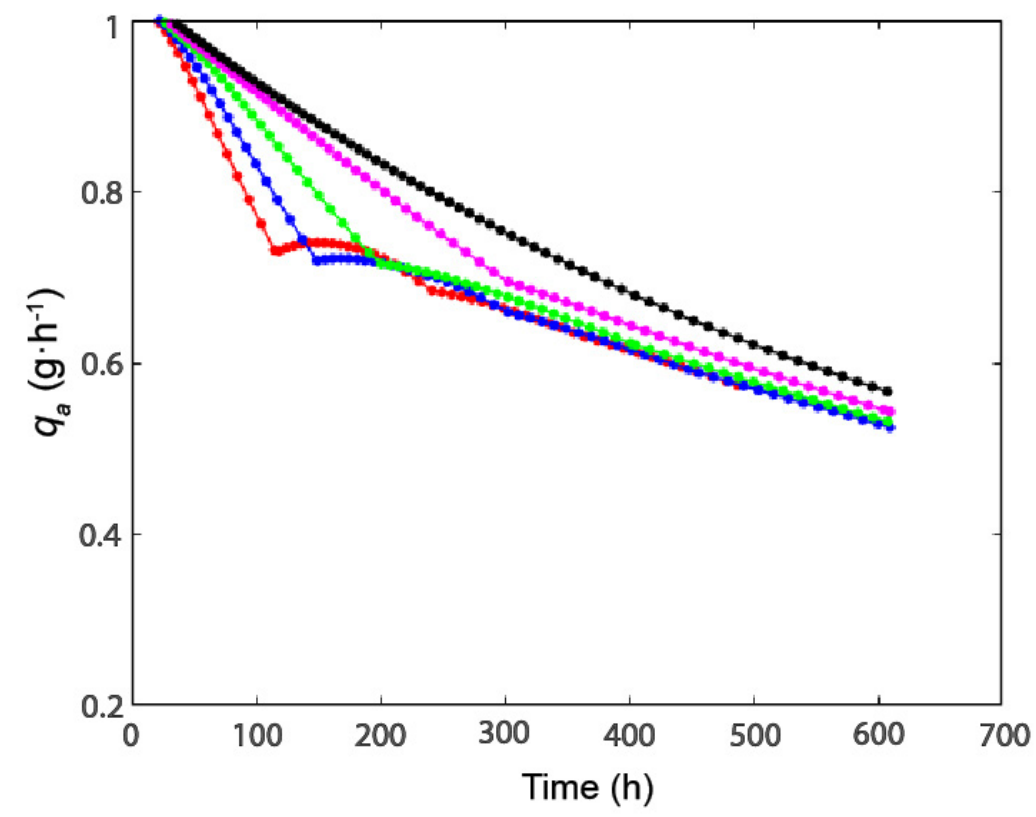

Figure 6. Variation in the accumulated productivity in the one-pot production of lactofructose syrup in sequential batch operation considering one cycle of use of GI and one or more cycles of $\beta$-gal use. Simulations were performed considering $40{ }^{\circ} \mathrm{C}, \mathrm{pH} 7,10 \%(w / w)$ of initial lactose concentration and GI/ $\beta$-gal activity ratio of $0.46\left(\mathrm{IU}_{\mathrm{GI}} / \mathrm{IU}_{\beta \text {-gal }}\right)$. Red line: $\eta=0$; blue line: $\eta=0.2$; green line: $\eta=0.4$; purple line: $\eta=0.6$; black line: $\eta=0.8$.

\section{Materials and Methods}

\subsection{Materials}

This study was conducted using the commercial immobilized GI from Streptomyces murinus under the trade name Sweetzyme ${ }^{\circledR} \mathrm{IT}$, kindly donated by Novozymes (Bagsvaerd, Denmark), and the commercial soluble $\beta$-gal from Aspergillus oryzae, under the trade name Enzeco ${ }^{\circledR}$ Fungal Lactase Concentrate, kindly provided by Enzyme Development Corporation (New York, NY, USA). In the case of $\beta$-gal, the enzyme was immobilized in a methacrylate heterofunctional support (Relizyme Resindion, Milano, Italy) [47,48] (more details in Supplementary Materials). All chemicals were purchased from Sigma-Aldrich (St. Louis, MO, USA). 


\subsection{Modeling}

The operation of a one-pot sequential batch reactor was simulated with $\beta$-gal and GI immobilized separately for the production of LFS from lactose. For process modeling purpose, a perfectly stirred and isothermal basket type reactor was used throughout the operation, and internal diffusional restrictions of the catalysts were not considered. For each batch of LFS production, the evolution of substrate and products concentrations was obtained, determining the specific productivity and the residual activity of both immobilized enzymes. As previously reported [8], the composition of LFS on a dry basis was: $6 \% w / w$ lactose, $47 \% w / w$ galactose, $26 \% w / w$ glucose, and $21 \% w / w$ fructose). Both immobilized enzymes were recovered at the end of each batch and used in the next one without intermediate addition of fresh catalyst. The cycle of use of each immobilized enzyme was defined as the number of batches that could be carried out until its activity dropped to $30 \%$ of its initial activity, which was the criterion adopted for its replacement. The specific productivity of the whole cycle of use for each immobilized enzyme was also determined. The scheme of the reactions involved is shown in Figure 1B.

\subsubsection{Enzyme Kinetics}

Rate equations and kinetic parameters were taken from the literature [28-30,49]. Hydrolysis of lactose by $\beta$-gal is competitively inhibited by galactose, so the rate equation corresponds to Equation (1).

$$
v_{1}=\frac{k_{c a t 1} \cdot e_{1} \cdot L a c}{K_{m 1} \cdot\left(1+\frac{L a c}{K_{I}}\right)+L a c}
$$

Temperature dependence of the kinetic parameters $\left(k_{c a t 1}, K_{M 1}\right.$ and $\left.K_{I}\right)$ are represented by Arrhenius type equations:

$$
\begin{gathered}
k_{\text {cat } 1}=k_{\text {cat } 01} \cdot \exp \left(-E_{a} / R T\right), \\
K_{M 1}=K_{M 0} \cdot \exp \left(-\Delta H^{\circ} / R T\right), \\
K_{I}=K_{I 0} \cdot \exp \left(-\Delta H^{\circ}{ }_{I} / R T\right) .
\end{gathered}
$$

Isomerization of glucose into fructose by GI is represented by reversible kinetics according to the steady-state hypothesis of Briggs-Haldane. At favorable conditions for GI, activity and operational stability, the equilibrium constant of the reaction is close to 1 so the glucose-fructose conversion at equilibrium is close to $50 \%$ [18]. The rate equation for glucose isomerization can be expressed in terms of the difference in glucose concentration and glucose concentration at equilibrium, as represented by Equation (5):

$$
v_{2}=\frac{V_{M 2} \cdot\left(G l u-G l u_{e}\right)}{K_{M 2}+\left(G l u-G l u_{e}\right)} .
$$

where:

$$
\begin{gathered}
G l u_{0}=G l u+F r u=G l u_{e}+F r u_{e}=\left(1+K_{e}\right) \cdot G l u_{e}=\left(1+K_{e}^{-1}\right) \cdot F r u_{e} \\
V_{M 2}=\left[1+\frac{1}{K}\right] \frac{K_{m r} \cdot k_{c a t 2} \cdot e_{2}}{K_{m r}-K_{m f}} \\
K_{M 2}=\frac{K_{m r} \cdot K_{m f}}{K_{m r}-K_{m f}}\left[1+\left(1+\left(\frac{1}{K_{m f}}+\frac{K_{e}}{K_{m r}}\right) \frac{G l u_{0}}{1+K_{e}}\right)\right]
\end{gathered}
$$


As in the case of lactose hydrolysis with $\beta$-gal, kinetic parameters of the isomerization reaction with GI $\left(k_{c a t 2}, K_{m f}, K_{m r}\right.$, and $\left.K_{e}\right)$ are represented by Arrhenius type equations:

$$
\begin{aligned}
k_{c a t 2} & =k_{c a t 02} \exp \left(\frac{E_{a V m f}}{R \cdot T}\right), \\
K_{m f} & =K_{m f 0} \exp \left(\frac{E_{a, K m f}}{R \cdot T}\right), \\
K_{m r} & =K_{m r 0} \exp \left(\frac{E_{a, K m r}}{R \cdot T}\right), \\
K_{e} & =K_{e 0} \exp \left(-\frac{E_{a K}}{R \cdot T}\right) .
\end{aligned}
$$

In the case of GI, the affinity constant $\left(K_{M 2}\right)$ depends on the initial concentration of glucose $\mathrm{Glu}_{0}$; therefore, the energy of activation and the frequency factor in $\mathrm{K}_{\mathrm{M}}$ vary with Glu

Dehkordi, et al. [49] observed that at constant temperature $\mathrm{K}_{\mathrm{M} 2}$ varied linearly with $G l u_{0}$, as expected, and reported a general equation for $\mathrm{K}_{\mathrm{M} 2}$ which is explicit in $G l u_{0}$ and $T$ :

$$
K_{M 2}=10.37 \cdot 10^{10} \exp ^{-\frac{7534}{T}} G l u_{0}+5.48 \cdot 10^{32} \exp ^{-\frac{22,818}{T}} .
$$

Values of the kinetic parameters of $\beta$-gal and GI immobilized used in the simulation of the production of lactofructose syrup are presented in Table 1. In this work, $\mathrm{pH} 7$ was considered for the one-pot production of LFS, which is a compromise between the $\mathrm{pH}$

\begin{tabular}{|c|c|c|c|c|}
\hline Enzyme & Parameter & Value & Unit & Reference \\
\hline$\beta$-gal & $\begin{array}{c}k_{c a t 01} \\
E_{a} \\
K_{M 0} \\
\Delta H^{\circ} \\
K_{I 0} \\
\Delta H^{\circ}{ }_{I} \\
\end{array}$ & $\begin{array}{c}6.74 \\
7.02 \\
1.01 \times 10^{7} \\
7.21 \\
1.32 \times 10^{2} \\
5.52 \\
\end{array}$ & $\begin{array}{c}\mathrm{mol} /(\mathrm{h} \cdot \mathrm{IU}) \\
\mathrm{kcal} / \mathrm{mol} \\
\mathrm{M} \\
\mathrm{kcal} / \mathrm{mol} \\
\mathrm{M} \\
\mathrm{kcal} / \mathrm{mol} \\
\end{array}$ & {$[29,30]$} \\
\hline GI & $\begin{array}{c}k_{c a t 02} \\
E_{a V m f} \\
K_{m f 0} \\
E a_{K m f} \\
K_{m r 0} \\
E a_{K m r} \\
K_{e 0} \\
E_{a K}\end{array}$ & $\begin{array}{c}1.46 \times 10^{15} \\
29.5 \\
1.35 \times 10^{21} \\
32.9 \\
5.27 \times 10^{13} \\
21.2 \\
4.10 \times 10^{4} \\
7.03\end{array}$ & $\begin{array}{c}\mathrm{mol} /(\mathrm{h} \cdot \mathrm{IU}) \\
\mathrm{kcal} / \mathrm{mol} \\
\mathrm{M} \\
\mathrm{kcal} / \mathrm{mol} \\
\mathrm{M} \\
\mathrm{kcal} / \mathrm{mol} \\
- \\
\mathrm{kcal} / \mathrm{mol}\end{array}$ & [49] \\
\hline
\end{tabular}
optima of $\beta$-gal and GI. In fact, the activity of GI decreases significantly below $\mathrm{pH} 7$, while $\beta$-gal is fairly active at $\mathrm{pH} 7$ even though its optimum $\mathrm{pH}$ is lower [8].

Table 1. Values of the kinetic parameters of $\beta$-gal and immobilized GI used in the simulation of the production of lactofructose syrup.

\subsubsection{Enzyme Inactivation}

Kinetics of enzyme inactivation for each enzyme was performed at $\mathrm{pH} 7$ and temperatures of 40,50 , and $60{ }^{\circ} \mathrm{C}$ under non-reactive conditions. The results obtained (see Supplementary Materials) were fitting to a one-step first-order kinetics of inactivation. However, stability under operation conditions may vary depending on the presence of modulators of enzyme stability, such as substrates and products of reactions $[40,41,43,50]$.

The equation for one-step first-order kinetics of inactivation under modulation can be expressed as:

$$
-\frac{d e}{d t}=k_{D} \cdot(1-\eta) \cdot e .
$$


Temperature dependence of the inactivation parameters is described by an Arrhenius type equation:

$$
k_{D}=k_{D 0} \cdot \exp \left(\frac{E_{a K_{D}}}{R \cdot T}\right) .
$$

The experimental data of inactivation of each of the immobilized enzymes under non-reactive conditions were adjusted by linear regression, using the function fminsearch of MATLAB ${ }^{\circledR}$, to obtain the values of the parameters of the Arrhenius equation, as shown in Table 2, and then used for the calculation of the inactivation constants $\left(k_{D}\right)$ of each immobilized enzyme at different temperatures, using Equation (15).

Table 2. Parameters of the Arrhenius equation for the determination of the inactivation rate $\left(\mathrm{k}_{\mathrm{D}}\right)$ of $\beta$-galactosidase and glucose isomerase.

\begin{tabular}{ccc}
\hline Parameters & $\beta$-gal & GI \\
\hline$E_{a K_{D}}(\mathrm{Kcal} / \mathrm{mol})$ & 73.46 & 34.83 \\
$k_{D 0}\left(\mathrm{~h}^{-1}\right)$ & $1.64 \times 10^{49}$ & 5.98 \\
\hline
\end{tabular}

3.2.3. Mathematical Model for the One-Pot Production of Lactofructose Syrup in Sequential Batch Operation

The proposed model considers that the liquid phase in the reactor is completely mixed so that lactose concentration is the same at any point inside the reactor. The model was built up from a material balance of substrates and products considering enzyme inactivation throughout reactor operation. Since in this case there are two reactions in series, the product of the first reaction (glucose) becomes the substrate of the second. The following equations describe the system:

$$
\begin{gathered}
\frac{d L a c}{d t}=-v_{1} \cdot \gamma_{1}, \\
\frac{d G a l}{d t}=v_{1} \cdot \gamma_{1}, \\
\frac{d G l u}{d t}=v_{1} \cdot \gamma_{1}-v_{2} \cdot \gamma_{2}, \\
\frac{d F r u}{d t}=v_{2} \cdot \gamma_{2}, \\
\frac{d \gamma_{1}}{d t}=-k_{D 1} \cdot(1-\eta) \cdot \gamma_{1}, \\
\frac{d \gamma_{2}}{d t}=-k_{D 2} \cdot \gamma_{2} .
\end{gathered}
$$

The operation curve of the one-pot sequential batch reactor (substrate conversion versus time) is obtained by the simultaneous solving of Equations (16)-(21). To do so, the proposed model was implemented in MATLAB ${ }^{\circledR}$, version R2019a and the equations were solved using ode23s solver.

Simulation of each batch during sequential batch operation was performed until reaching $90 \%$ conversion of lactose into glucose and $45 \%$ conversion of glucose into fructose. The GI/ $\beta$-gal activity ratio is:

$$
R=\frac{e_{2}}{e_{1}} .
$$

The enzyme concentration of each enzyme, can be determined from the mass balance as:

$$
\begin{gathered}
e_{1}=\frac{M_{\text {cat }} \cdot a_{1}}{V_{r} \cdot\left(1+\frac{R \cdot a_{1}}{a_{2}}\right)}, \\
e_{2}=\left(\frac{M_{\text {cat }}}{V_{r}}-\frac{e_{1}}{a_{1}}\right) \cdot a_{2} .
\end{gathered}
$$




\subsubsection{Reactor Operation Conditions}

The number of batches that can be performed within one cycle of use of an immobilized enzyme will depend on the process operating conditions, since the two enzymes have different kinetic properties and a great difference in operational stability. To enable the selective replacement of each immobilized enzyme, simulation was carried out considering a compartmentalized basket enzyme reactor, where the immobilized enzymes were contained in separate compartments in order to be manipulated independently (Figure 1).

The simulation of reactor operation was carried out at different temperatures, and kinetic and stability parameters were expressed as explicit functions of temperature using the above Arrhenius type equations. Each batch was performed at $0.3 \mathrm{M}$ lactose $(10 \% w / w)$ and $\mathrm{pH} 7$, until reaching $90 \%$ lactose conversion and a minimum of $45 \%$ glucose isomerization ( $90 \%$ of the equilibrium conversion). Since the operating criterion adopted for sequential batch operation was a constant conversion of both reactions at the end of each batch, and there was no addition of fresh immobilized enzymes, the time for each batch progressively increases as the enzymes were inactivated.

\subsection{Metrics Used in Reactor Operations}

The following parameters were used for describing reactor operation:

Lactose conversion: the mass fraction of lactose hydrolyzed in the reactor:

$$
x_{L a c}=\frac{L a c_{0}-L a c}{L a c_{0}} .
$$

Productivity: the mass of fructose produced per unit reaction time, calculated at $90 \%$ lactose conversion

$$
q=\frac{V_{r} \cdot F r u \cdot M W_{F}}{t} .
$$

Accumulated productivity: the total mass of fructose produced in the $\mathrm{m}$ batches that make up the cycle of use of the immobilized enzymes, divided by the accumulated time of the $\mathrm{m}$ batches, calculated at $90 \%$ lactose conversion:

$$
q_{a}=\frac{V_{r} \cdot M W_{F} \sum_{1}^{m} F r u_{i}}{\sum_{1}^{m} t_{i}} .
$$

Accumulated specific productivity: the total mass of fructose produced in the $\mathrm{m}$ batches that make up the cycle of use of the immobilized enzyme, divided by the accumulated time of the $m$ batches and the mass of immobilized enzyme ( $\beta$-gal or GI) calculated at $90 \%$ lactose conversion:

$$
Q_{j}=\frac{V_{r} \cdot M W_{F} \sum_{1}^{m} F r u_{i}}{\left(\sum_{1}^{m} t_{i}\right) \cdot M_{j}} .
$$

\section{Conclusions}

This work presents the design of a strategy of catalysts replacement in a multienzyme one-pot system operating in sequential batch operation, with each enzyme immobilized separately according to their respective stabilities. This strategy is useful when the stabilities of the enzymes differ significantly, since each enzyme can be individually replaced once the criterion for replacement has been reached, thus enabling a better use of each enzyme activity. However, this is not feasible when the enzymes are co-immobilized, where the less stable enzyme will determine the criterion for biocatalyst replacement, while the more stable enzyme may still be quite active.

Having a mathematical model to simulate the one-pot reactor operation allows establishing the strategies for the replacement of each immobilized enzyme considering their individual stabilities, therefore establishing a proper operational schedule for increasing productivity and thus boosting the profitability of the process. 
This work shows that it is feasible and convenient to carry out the one-pot sequential batch operation with the enzymes immobilized separately when the stabilities of the enzymes are significantly different. We envision that this strategy could be applied to any multienzyme system operating in a single pot for an effective use and replacement of the biocatalyst with the concomitant benefits in the economics of the process.

Supplementary Materials: The following are available online at https:/ /www.mdpi.com/article/ 10.3390/catal11101167/s1: detailed description of the material and method regarding enzymes activity assays and immobilization; Figure S1: Immobilization kinetics of $\beta$-gal; Figure S2: Effect of temperature on the stability of $\beta$-gal; Tables S1 and S2: Inactivation parameters of $\beta$-gal; Figure S3: Effect of temperature on the stability of GI; Tables S3 and S4: Inactivation parameters of GI; Figure S4: Effect of the GI/ $\beta$-gal activity ratio (R) on the productivity (q) at different reaction temperatures; Table S5: Summary of the results the simulation of the one-pot production of lactofructose syrup.

Author Contributions: Conceptualization, L.W., O.R. and A.I.; methodology, V.A., D.C. and P.S.; software, V.A., D.C. and P.S.; validation, P.S.; formal analysis, L.W., P.S. and A.I.; investigation, V.A. and D.C.; writing—original draft preparation, P.S., L.W., O.R. and A.I.; writing-review and editing, L.W., O.R. and A.I.; visualization, V.A. and D.C.; supervision, L.W., O.R. and A.I.; project administration, L.W., O.R. and A.I.; funding acquisition, L.W. All authors have read and agreed to the published version of the manuscript.

Funding: This work was supported by FONDECYT-Chile (Grant number 1190709). Pablo Silva acknowledges funding from PUCV for a doctoral fellowship. Daniela Cid and Vanessa Arancibia acknowledges funding from VRIEA-PUCV (project no. 039.418/19).

Data Availability Statement: The data presented in this study are available in the present article and in Supplementary Materials.

Acknowledgments: We thank Ramiro Martinez, from Novozymes A/S, Spain, for supplying commercial enzymes.

Conflicts of Interest: The authors declare no conflict of interest.

\section{Nomenclature}

$\beta$-gal: $\quad \beta$-galactosidase

GI: glucose isomerase

$a_{1}: \quad$ specific activity of $\beta$-gal (IU/g)

$\mathrm{a}_{2}: \quad$ specific activity of $\mathrm{GI}(\mathrm{IU} / \mathrm{g})$

$\mathrm{e}_{1}: \quad$ enzyme concentration of $\beta$-gal (IU/L)

$\mathrm{e}_{2}: \quad$ enzyme concentration of GI (IU/L)

$\mathrm{E}_{\mathrm{a}}$ : activation energy $(\mathrm{Kcal} / \mathrm{mol})$

Fru: fructose concentration (M)

Frue: equilibrium concentration of fructose $(\mathrm{M})$

Gal: $\quad$ galactose concentration (M)

Glu: $\quad$ glucose concentration (M)

$\mathrm{Glu}_{0}$ : initial concentration of glucose $(\mathrm{M})$

Glue: equilibrium concentration of glucose (M)

$\Delta \mathrm{H}^{\circ}: \quad$ standard enthalpy change of dissociation of $\beta$-gal-lactose into $\beta$-gal and lactose $(\mathrm{Kcal} / \mathrm{mol})$

$\Delta \mathrm{H}^{\circ} \mathrm{I}$ : standard enthalpy change of dissociation of $\beta$-gal-galactose into $\beta$-gal and galactose $(\mathrm{Kcal} / \mathrm{mol})$

kcat $_{1}$ : catalytic rate constant of $\beta$-gal (mol/(h.IU))

$\mathrm{k}_{\mathrm{D} 1}$ : $\quad$ thermal decay constant of $\beta$-gal $\left(\mathrm{h}^{-1}\right)$

$\mathrm{k}_{\mathrm{D} 2}$ : thermal decay constant of glucose isomerase $\left(\mathrm{h}^{-1}\right)$

$\mathrm{k}_{\mathrm{D}^{\prime}}$ : $\quad$ thermal decay constant under operational conditions $\left(\mathrm{h}^{-1}\right)$

$\mathrm{K}_{\mathrm{e}}$ : $\quad$ equilibrium constant of GI

$\mathrm{K}_{\mathrm{I}}: \quad$ inhibition constant of $\beta$-gal by galactose $(\mathrm{M})$

$\mathrm{Km}_{1}$ : $\quad$ Michaelis-Menten constant for $\beta$-gal $(\mathrm{M})$

$\mathrm{Km}_{2}: \quad$ apparent Michaelis-Menten constant of GI (M)

$\mathrm{Km}_{\mathrm{f}}: \quad$ Michaelis-Menten constant for fructose (mol)

$\mathrm{Km}_{\mathrm{g}}$ : Michaelis-Menten constant for glucose (mol) 


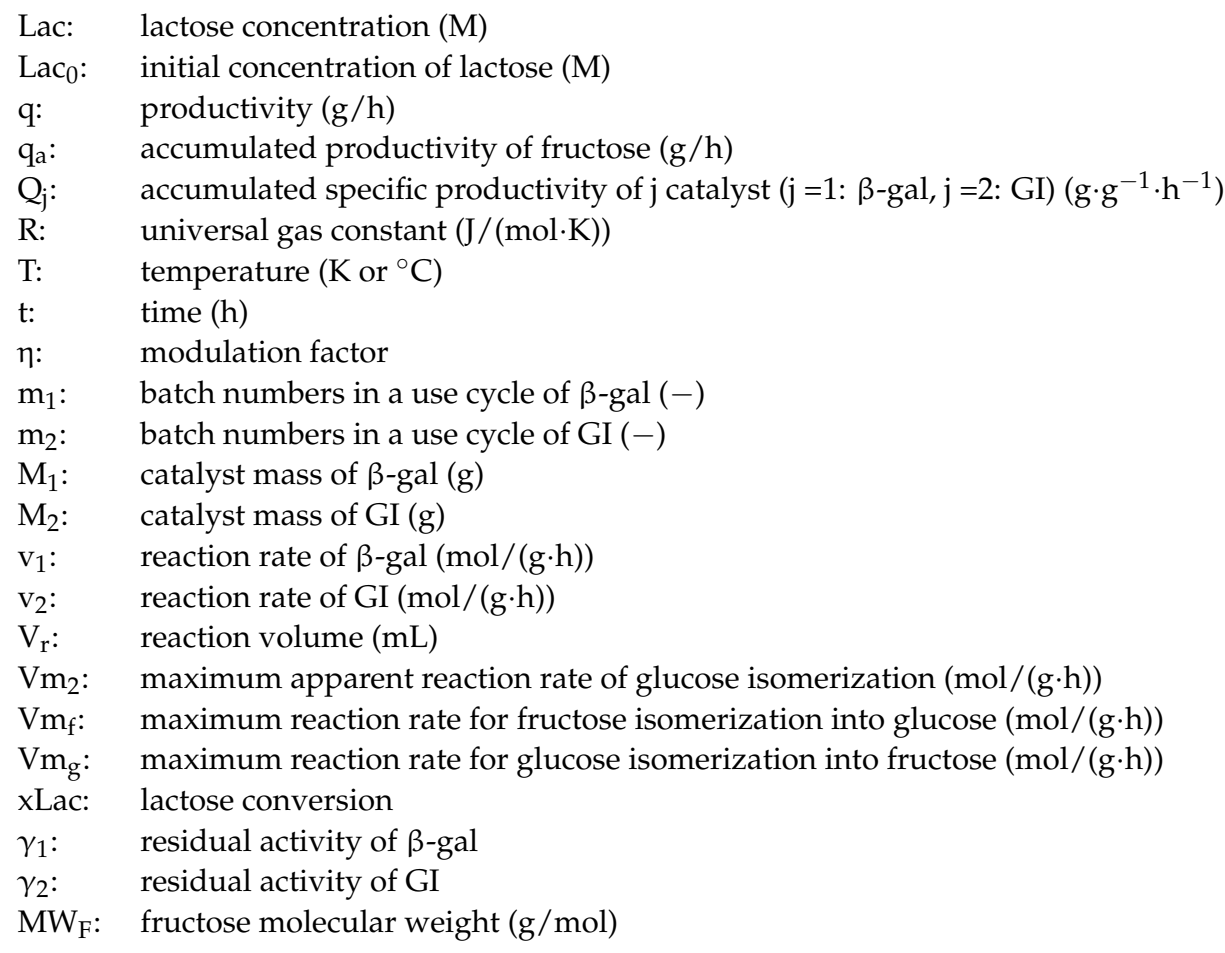

\section{References}

1. Katsimpouras, C.; Stephanopoulos, G. Enzymes in biotechnology: Critical platform technologies for bioprocess development. Curr. Opin. Biotechnol. 2021, 69, 91-102. [CrossRef]

2. Torres-León, C.; Chávez-González, M.L.; Hernández-Almanza, A.; Martínez-Medina, G.A.; Ramírez-Guzmán, N.; Londoño-Hernández, L.; Aguilar, C.N. Recent advances on the microbiological and enzymatic processing for conversion of food wastes to valuable bioproducts. Curr. Opin. Food Sci. 2021, 38, 40-45. [CrossRef]

3. Suresh, A.; Shravan Ramgopal, D.; Panchamoorthy Gopinath, K.; Arun, J.; SundarRajan, P.; Bhatnagar, A. Recent advancements in the synthesis of novel thermostable biocatalysts and their applications in commercially important chemoenzymatic conversion processes. Bioresour. Technol. 2021, 323, 124558. [CrossRef]

4. Ren, S.; Li, C.; Jiao, X.; Jia, S.; Jiang, Y.; Bilal, M.; Cui, J. Recent progress in multienzymes co-immobilization and multienzyme system applications. Chem. Eng. J. 2019, 373, 1254-1278. [CrossRef]

5. Ji, Q.; Wang, B.; Tan, J.; Zhu, L.; Li, L. Immobilized multienzymatic systems for catalysis of cascade reactions. Process Biochem. 2016, 51, 1193-1203. [CrossRef]

6. Sheldon, R.A.; Brady, D. Streamlining design, engineering, and applications of enzymes for sustainable biocatalysis. ACS Sustain. Chem. Eng. 2021, 9, 8032-8052. [CrossRef]

7. Santacoloma, P.A.; Sin, G.; Gernaey, K.V.; Woodley, J.M. Multienzyme-catalyzed processes: Next-generation biocatalysis. Org. Process Res. Dev. 2011, 15, 203-212. [CrossRef]

8. Araya, E.; Urrutia, P.; Romero, O.; Illanes, A.; Wilson, L. Design of combined crosslinked enzyme aggregates (combi-CLEAs) of $\beta$-galactosidase and glucose isomerase for the one-pot production of fructose syrup from lactose. Food Chem. 2019, 288, 102-107. [CrossRef]

9. Velasco-Lozano, S.; López-Gallego, F. Wiring step-wise reactions with immobilized multi-enzyme systems. Biocatal. Biotransform. 2018, 36, 184-194. [CrossRef]

10. Torres, P.; Batista-Viera, F. Immobilized trienzymatic system with enhanced stabilization for the biotransformation of lactose. Molecules 2017, 22, 284. [CrossRef] [PubMed]

11. Hwang, E.T.; Lee, S. Multienzymatic Cascade Reactions via Enzyme Complex by Immobilization. ACS Catal. 2019, 9, 4402-4425. [CrossRef]

12. Dubey, N.C.; Tripathi, B.P. Nature inspired multienzyme immobilization: Strategies and concepts. ACS Appl. Bio Mater. 2021, 4, 1077-1114. [CrossRef]

13. Riva, S.; Fessner, W.D. Cascade Biocatalysis: Integrating Stereoselective and Environmentally Friendly Reactions; John Wiley \& Sons: Weinheim, Germany, 2014; pp. 1-465, ISBN 9783527335220.

14. Xue, R.; Woodley, J.M. Process technology for multi-enzymatic reaction systems. Bioresour. Technol. 2012, 115, 183-195. [CrossRef]

15. Wang, Z.; Sundara Sekar, B.; Li, Z. Recent advances in artificial enzyme cascades for the production of value-added chemicals. Bioresour. Technol. 2021, 323, 124551. [CrossRef] 
16. Arana-Peña, S.; Carballares, D.; Corberan, V.C.; Fernandez-Lafuente, R. Multi-combilipases: Co-immobilizing lipases with very different stabilities combining immobilization via interfacial activation and ion exchange. The reuse of the most stable co-immobilized enzymes after inactivation of the least stable ones. Catalysts 2020, 10, 1207. [CrossRef]

17. Wilson, L.; Illanes, A.; Ottone, C.; Romero, O. Co-immobilized carrier-free enzymes for lactose upgrading. Curr. Opin. Green Sustain. Chem. 2021, in press.

18. Illanes, A. Enzyme Biocatalysis: Principles and Applications; Springer: Dordrecht, The Netherlands, 2008; pp. 1-391. [CrossRef]

19. Illanes, A.; Wilson, L.; Raiman, L. Design of immobilized enzyme reactors for the continuous production of fructose syrup from whey permeate. Bioprocess Eng. 1999, 21, 509-515. [CrossRef]

20. Velasco-Lozano, S. Immobilization of enzymes as cross-linked enzyme aggregates: General strategy to obtain robust biocatalysts. In Methods in Molecular Biology; Humana: New York, NY, USA, 2020; Volume 2100, pp. 345-361.

21. Arana-Peña, S.; Carballares, D.; Morellon-Sterlling, R.; Berenguer-Murcia, Á.; Alcántara, A.R.; Rodrigues, R.C.; Fernandez-Lafuente, R. Enzyme co-immobilization: Always the biocatalyst designers' choice... or not? Biotechnol. Adv. 2021, 51, 107584. [CrossRef] [PubMed]

22. Bolivar, J.M.; López-Gallego, F. Characterization and evaluation of immobilized enzymes for applications in flow reactors. Curr. Opin. Green Sustain. Chem. 2020, 25, 100349. [CrossRef]

23. Adloor, S.D.; Pons, T.; Vassiliadis, V.S. An optimal control approach to scheduling and production in a process using decaying catalysts. Comput. Chem. Eng. 2020, 135, 106743. [CrossRef]

24. Shafi, A.; Ahmed, F.; Husain, Q. $\beta$-Galactosidase mediated synthesized nanosupport for the immobilization of same enzyme: Its stability and application in the hydrolysis of lactose. Int. J. Biol. Macromol. 2021, 184, 57-67. [CrossRef]

25. Neifar, S.; Cervantes, F.V.; Bouanane-Darenfed, A.; BenHlima, H.; Ballesteros, A.O.; Plou, F.J.; Bejar, S. Immobilization of the glucose isomerase from Caldicoprobacter algeriensis on Sepabeads EC-HA and its efficient application in continuous High Fructose Syrup production using packed bed reactor. Food Chem. 2020, 309, 125710. [CrossRef]

26. Guerrero, C.; Súarez, S.; Aburto, C.; Ubilla, C.; Ramírez, N.; Vera, C.; Illanes, A. Comparison of batch and repeated batch operation of lactulose synthesis with cross-linked aggregates of Bacillus circulans $\beta$-galactosidase. Process Biochem. 2020, 94, 224-234. [CrossRef]

27. Jia, D.X.; Zhou, L.; Zheng, Y.G. Properties of a novel thermostable glucose isomerase mined from Thermus oshimai and its application to preparation of high fructose corn syrup. Enzym. Microb. Technol. 2017, 99, 1-8. [CrossRef]

28. Guerrero, C.; Vera, C.; Illanes, A. Optimisation of synthesis of oligosaccharides derived from lactulose (fructosyl-galactooligosaccharides) with $\beta$-galactosidases of different origin. Food Chem. 2013, 138, 2225-2232. [CrossRef]

29. Vera, C.; Guerrero, C.; Illanes, A.; Conejeros, R. A pseudo steady-state model for galacto-oligosaccharides synthesis with $\beta$-galactosidase from Aspergillus oryzae. Biotechnol. Bioeng. 2011, 108, 2270-2279. [CrossRef] [PubMed]

30. Vera, C.; Guerrero, C.; Illanes, A. Determination of the transgalactosylation activity of Aspergillus oryzae $\beta$-galactosidase: Effect of $\mathrm{pH}$, temperature, and galactose and glucose concentrations. Carbohydr. Res. 2011, 346, 745-752. [CrossRef] [PubMed]

31. Hartley, B.S.; Hanlon, N.; Jackson, R.J.; Rangarajan, M. Glucose isomerase: Insights into protein engineering for increased thermostability. Biochim. Biophys. Acta Protein Struct. Mol. Enzymol. 2000, 1543, 294-335. [CrossRef]

32. Converti, A.; Del Borghi, M. Simultaneous effects of immobilization and substrate protection on the thermodynamics of glucose isomerase activity and inactivation. Enzym. Microb. Technol. 1997, 21, 511-517. [CrossRef]

33. Amaral-Fonseca, M.; Morellon-Sterling, R.; Fernández-Lafuente, R.; Tardioli, P.W. Optimization of simultaneous saccharification and isomerization of dextrin to high fructose syrup using a mixture of immobilized amyloglucosidase and glucose isomerase. Catal. Today 2021, 362, 175-183. [CrossRef]

34. Lorenzen, P.C.; Breiter, J.; Clawin-Rädecker, I.; Dau, A. A novel bi-enzymatic system for lactose conversion. Int. J. Food Sci. Technol. 2013, 48, 1396-1403. [CrossRef]

35. Motiei, M.; Mirahmadi-Zare, S.Z.; Nasr-Esfahani, M.H. Chemical stabilization of $\gamma$-polyglutamate by chitosan and the effect of co-solvents on the stability. Biophys. Chem. 2021, 275, 106605. [CrossRef] [PubMed]

36. Piszkiewicz, S.; Pielak, G.J. Protecting enzymes from stress-induced inactivation. Biochemistry 2019, 58, 3825-3833. [CrossRef] [PubMed]

37. Goswami, S.; Gupta, N.; Datta, S. Using the b-glucosidase catalyzed reaction product glucose to improve the ionic liquid tolerance of B-glucosidases. Biotechnol. Biofuels 2016, 9, 72. [CrossRef]

38. Illanes, A.; Wilson, L.; Tomasello, G. Temperature optimization for reactor operation with chitin-immobilized lactase under modulated inactivation. Enzym. Microb. Technol. 2000, 27, 270-278. [CrossRef]

39. Prestrelski, S.J.; Tedeschi, N.; Arakawa, T.; Carpenter, J.F. Dehydration-induced conformational transitions in proteins and their inhibition by stabilizers. Biophys. J. 1993, 65, 661-671. [CrossRef]

40. Xu, X.Q.; Shi, Y.; Wu, X.B.; Zhan, X.L.; Zhou, H.T.; Chen, Q.X. Heat inactivation kinetics of Hypocrea orientalis $\beta$-glucosidase with enhanced thermal stability by glucose. Int. J. Biol. Macromol. 2015, 81, 1012-1018. [CrossRef]

41. Illanes, A.; Wilson, L.; Tomasello, G. Effect of modulation of enzyme inactivation on temperature optimization for reactor operation with chitin-immobilized lactase. J. Mol. Catal.-B Enzym. 2001, 11, 531-540. [CrossRef]

42. Chen, K.C.; Wu, J.Y. Substrate protection of immobilized glucose isomerase. Biotechnol. Bioeng. 1987, 30, 817-824. [CrossRef]

43. Villaume, I.; Thomas, D.; Legoy, M.D. Catalysis may increase the stability of an enzyme: The example of horse liver alcohol dehydrogenase. Enzym. Microb. Technol. 1990, 12, 506-509. [CrossRef] 
44. Illanes, A.; Altamirano, C.; Zuñiga, M.E. Thermal inactivation of immobilized penicillin acylase in the presence of substrate and products. Biotechnol. Bioeng. 1996, 50, 609-616. [CrossRef]

45. Faqir, N.M.; Abu-Reesh, I.M. Optimum temperature operation mode for glucose isomerase reactor operating at constant glucose conversion. Bioprocess Eng. 1998, 19, 11-17. [CrossRef]

46. Park, S.H.; Lee, S.B.; Ryu, D.D.Y. Optimization of operating temperature for continuous glucose isomerase reactor system Biotechnol. Bioeng. 1981, 23, 1237-1254. [CrossRef]

47. Mateo, C.; Bolivar, J.M.; Godoy, C.A.; Rocha-Martin, J.; Pessela, B.C.; Curiel, J.A.; Muñoz, R.; Guisan, J.M.; Fernández-Lorente, G. Improvement of enzyme properties with a two-step immobilizaton process on novel heterofunctional supports. Biomacromolecules 2010, 11, 3112-3117. [CrossRef] [PubMed]

48. Guerrero, C.; Vera, C.; Serna, N.; Illanes, A. Immobilization of Aspergillus oryzae $\beta$-galactosidase in an agarose matrix functionalized by four different methods and application to the synthesis of lactulose. Bioresour. Technol. 2017, 232, 53-63. [CrossRef] [PubMed]

49. Dehkordi, A.M.; Tehrany, M.S.; Safari, I. Kinetics of glucose isomerization to fructose by immobilized glucose isomerase (Sweetzyme IT). Ind. Eng. Chem. Res. 2009, 48, 3271-3278. [CrossRef]

50. Ospina, S.S.; Lopez-Munguia, A.; Gonzalez, R.L.; Quintero, R. Characterization and use of a penicillin acylase biocatalyst. J. Chem. Technol. Biotechnol. 1992, 53, 205-213. [CrossRef] [PubMed] 